\title{
Financial Development and Economic Growth in Kenya: An Empirical Analysis 1980-2011
}

\author{
Susan Moraa Onuonga ${ }^{1}$ \\ ${ }^{1}$ School of Economics, Kenyatta University, Kenya \\ Correspondence: Susan Moraa Onuonga, School of Economics, Kenyatta University, Kenya. E-mail: \\ smo602000@yahoo.com or okeri.susanm@ku.ac.ke
}

Received: March 24, 2014

Accepted: April 16, 2014

Online Published: June 25, 2014

doi:10.5539/ijef.v6n7p226

URL: http://dx.doi.org/10.5539/ijef.v6n7p226

\begin{abstract}
The paper examined the empirical relationship between economic growth and financial development (FD) in Kenya over the period 1980-2011. The long-run and short-run parameters were estimated by use of autoregressive distributed lag (ARDL) bounds testing approach for co integration analysis. To determine the direction of causality, Granger causality analysis was done. Empirical findings indicate that there is stable long-run relationship among, financial development, trade openness and economic growth in Kenya. It also finds that financial development has a significant positive effect on economic growth. The magnitudes of the ECT coefficients suggest that the speed of adjustment in each of the estimated model is very high. The Granger causality tests showed that there is bi-directional causality between financial development and economic growth in Kenya for the period under study (1980-2011). This result therefore, supports both the supply leading, and demand following hypotheses. This means that financial development accelerates and augments economic growth in Kenya and that economic growth leads to development of the financial sector in Kenya. Thus, the government should strengthen the reforms in the financial sector so as to attract investors and improve the efficiency of all production activities in the country. At the same time, the government should enhance macroeconomic policies; fiscal policies, policies that attract foreign direct investment, and export promotion policies that on average lead to economic growth should.
\end{abstract}

Keywords: financial development, economic growth, ARDL bounds test, cointegration, granger causality, Kenya

\section{Introduction}

One of the issues economists have debated on is the role of financial development on economic growth of a country. What has been confirmed by many studies is that financial development has a positive impact on economic growth (King \& Levine, 1993; Goldsmith, 1969; Ndebbo, 2004; Goldsmith, 1973; McKinnon, 1973; Shaw, 1973). Since the pioneering work of Schumpeter (1911), a lot of both theoretical and empirical literature has been developed. The findings of the study showed that financial institutions contribute to economic growth by identifying and redirecting funds towards innovative projects. Schumpeter (1911) arguments were supported by McKinnon (1973) and Shaw (1973), who argued against financial repression adopted by many developing countries. They argued that the government's controls on financial sector such as setting maximum interest rates requiring huge amount of reserve requirements and directing credit programs deter both financial development and economic growth of the country. High interest rates attract savings. With high amounts of savings, commercial banks will have more credit which they can supply to the private sector for investment; this impacts economic development positively.

Financial development contributes to economic growth by stimulating investment in the country through the level and efficiency effects. The efficiency effect argues that the reforms and regulations in the financial sector ensure transparency and proper reporting systems within the sector; this ensures investors confidence thus, attracts both domestic and foreign investors. In addition, the efficiency effect argues that financial sector allocates financial resources to the most profitable projects. The efficiency effect implies that financial development and economic growth are positively correlated. This view is supported by the correlation matrix in Table 1.

A developed financial sector improves the efficiency and effectiveness of financial institutions and also promotes 
financial innovations within the sector. This promotes economic development. The financial sector is said to develop when: financial inclusion increases, the sector's stability increases, the amount of money that is intermediated by the financial institutions within the country increases, the number of financial institutions increase, the number of services or products offered increase and improve, the sector becomes more competitive and more efficient (DFID, 2004). This means there is no single measure that that can include all dimensions of financial development.

One way which can enable a country to achieve high economic growth is by building a capacity to mobilize financial resources and by ensuring their efficient allocation to the projects with highest returns. The financial sector does this role by mobilizing savings and allocating these resources to the most productive projects. Other roles of the financial sector that promote economic growth include risk management, obtaining information on investment opportunities, facilitating the exchange of goods and services, facilitating and encouraging inflows of foreign direct investment, amelioration of information asymmetries, among others (Levine, 1997; DFID, 2004). Although research in the area of the relationship between financial development and economic growth abound both in advanced and developing countries, the direction of causality has not been resolved. From the findings, it is not clear whether financial development is the cause of economic growth or economic growth is cause of financial development. Several views on the direction of causality between financial development and economic growth have been observed.

Another view, referred to as supply leading hypothesis, argues that financial development cause economic growth. It asserts that the financial sector mobilizes savings, allocates resources efficiently, mitigates the problem of asymmetric information, monitors firms, manages risk and reduces transaction costs among others; all these, according to the hypothesis contribute positively to economic growth. King and Levine (1993) argue that financial institutions increase capital accumulation and also influence the productivity of the factors of production positively; they opine that these two roles are critical in stimulating economic growth. This view is also supported by Patrick (1966) who argues that financial sector stimulates economic development by mobilizing savings and redirecting them to the highest rates of return on investment.

In opposition to the above postulation is the demand following hypothesis; it suggest that it is economic growth that cause financial development. It concludes that the growth of financial sector is in response to the demand created by economic development of a country (Robinson, 1952; Gurley \& Shaw, 1955; Goldsmith, 1969; Patrick, 1966). Thus, as the demand for financial services increase, inducement for growth of the financial sector results from the economy growth. This means that the factors that determine economic growth are not within the confines of the financial sector.

The other view is that there is bi-causality (feedback hypothesis) between financial development and economic. It argues that while economic growth can cause financial development, financial development can also lead to economic growth. This argument supports both the supply leading and demand following hypotheses (Demetriades \& Hussein, 1996; Greenwood \& Smith, 1997). The last view is that financial development and economic growth are independent (Lucas, 1988). This means they are not correlated in any way. Factors that explain the development of the economy or the financial sector are elsewhere.

Although many studies on finance-growth nexus have been done in both developing and advanced countries, similar studies in Kenya are very few. This study investigates the relationship between financial development and economic growth using the data over the period 1980-2011. Several developments have taken place in the financial sector in Kenya that may affect this relationship. Notable among such changes include financial reforms; the financial institutions have increased in number, the sector has developed and there have been several financial innovations. The study adds value to the previous studies in Kenya by using more recent data, controlling for other factors that affect growth and using a methodology of the ARDL bounds test for co-integration. The study also distinguishes between long-run and short- run causality. This is because the effects of high financial development can be realized in the short-run but in the long run they may disappear (Darrat, 1999).

\section{Financial Sector in Kenya}

According to Kenya`s Vision 2030, the financial sector will play a critical role in achieving the aim of the Vision by providing better intermediation between the surplus and deficit sectors of the economy (Republic of Kenya, 2007). There is the need for empirical evidence on the existence of long-run relationship between financial development and economic growth whether financial development causes economic growth or vice versa.

Kenya's financial sector is divided into two: the formal and informal. The formal sub-sector comprises of the banking, insurance, capital markets, pension funds, Savings and Credit Cooperative societies (SACCOs), 
Development Finance Institutions (Republic of Kenya, 2007; CBK et al., 2011). This sector also includes the financial infrastructure that facilitates trading, payments and settlement systems. On the other hand, the informal financial sub-sector is a sector that is unregulated but offers financial services. The institutions and group that are included here are the Rotating savings and Credit Associations (ROSCAs ) and Accumulating Savings and Credit Association (ASCAs,) merry go rounds popularly known as chamas in Kenya, shopkeepers and Money lenders among others (Central Bank of Kenya et al., 2011).

The Kenyan financial sector is dominated by the commercial banks. By the end of the year 2011, the banking sector in Kenya comprised of the Central Bank of Kenya (the regulatory authority), 44 banking institutions, 4 representative offices of foreign banks, 6 deposit-taking micro-finance institution, 118 forex bureaus and 2 Credit Reference Bureaus. Majority of the banks are locally owned, and only 13 are foreign owned.

Several developments have taken place in the financial sector between 1980 and 2011. The guidelines on the appointment and operations of the Third Party Agents by Deposit Taking Micro-finance institutions have been set and implemented.

Mobile banking has also increased over time. The total number of commercial bank agents increased by around 29 per cent in the 2011 from an increase of 71 percent in the year 2010. Commercial bank agents receive small cash deposits and withdrawals of bank customers. Thus, the total numbers of agents have increased with time and the same upward trend is observed in the number of customers who reached 19.2 million by 2011. Total transactions value has increased tremendously between 2007 and 2011. By the year 2011, total mobile money transfer increased to Kshs. 1,169.2 billion as compared to Kshs. 732.2 billion in the previous year.

A notable dimension in the financial sector is the expansion of the Deposit- Taking Microfinance (DTMs) sub-sector. The DTMs target the low and middle income entrepreneurs by providing them access to credit and other services that impacts positively to the country's economic growth. The other services they offer include business management skills to their clients. They have been critical since they also participate in credit allocation to the private sector and by June 2011 the 6 DTMs had given gross loans and advances totaling Kshs. 15.2 billion. It is notable that the banks have grown in number and in terms of branches and the sector has also expanded in the form of growth of the automated Teller machines (ATMs). It is estimated that by June 2011 there were 2183 ATMs in the country. This increase is attributed to banking sector business expansion strategies and high competition within the banking sector.

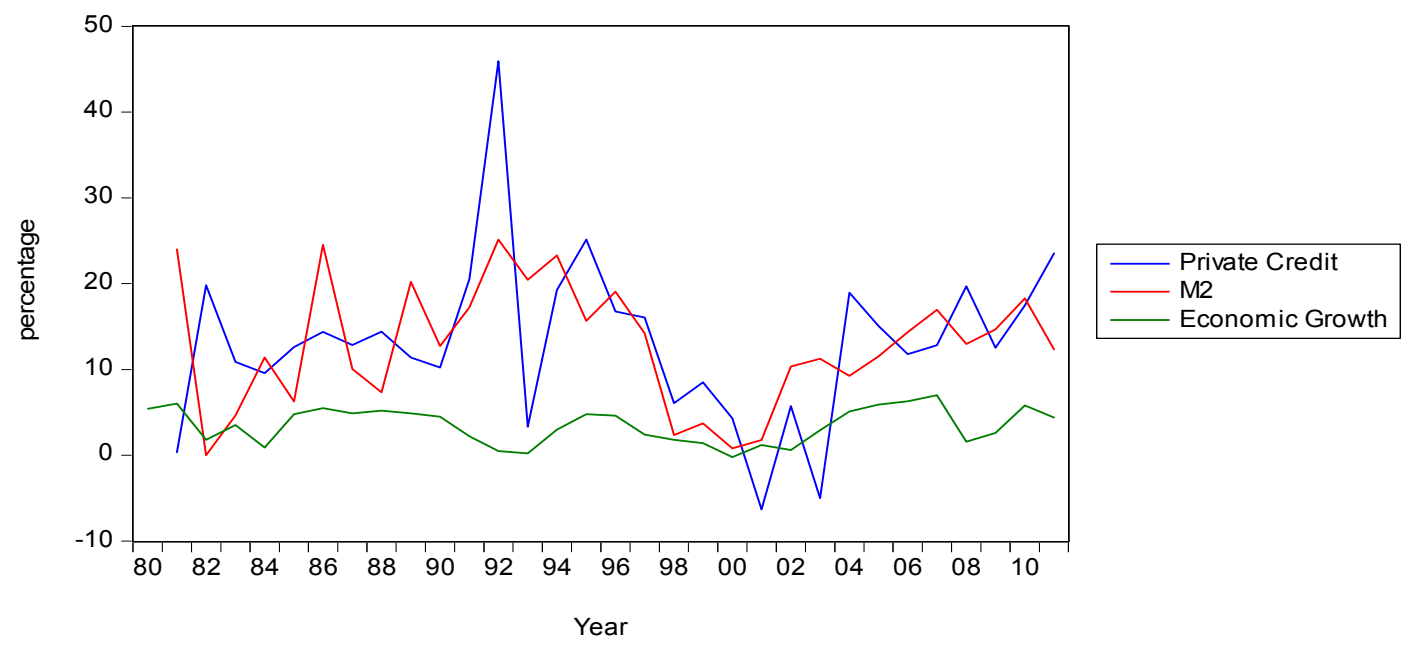

Figure 1. Trends of M2, real GDP growth rates and private credit

Source: Republic of Kenya, Economic Survey (various Issues).

Credit Reference Bureaus (CRBs) have been set up; these CRBs, launched in July 2010, and are being used by many institutions (Central Bank of Kenyan, 2012). Through the CRBs, banks are able to know the credit history of loan applicants and make informed decisions on probability of loan repayments by the customers. In addition, there has also been establishment of representative offices of foreign banks and by the end of 2011 there were 5 foreign banks that operated representative offices in Kenya. All these may affect the relationship between economic growth and development of the financial sector and the developments are projected to influence 
economic growth of a country positively.

There are several indicators of financial development. Figure 1, shows growths of M2, credit supplied to the private sector and Kenya' economic growth 1980-2011. On average, growth of the two financial development indicators (M2 and domestic credit to the private sector) is above real GDP growth over the study period.

Kenya's M2 increased by 12 percent in 2011 as compared to 18 percent in the year 2010 and credit supplied to the private sector increased by 23 percent in 2011 as compared to 17 percent in 2010. However, economic growth, as seen in the graph over the years, has been below the growth rate of the financial sector; in 2011 Kenya's GDP increased by 4.4 percent compared to 5.8 percent growth in 2010 . From the figure above, one cannot be able to tell whether financial development cause economic growth or it is economic growths that cause financial development. This paper examines the long-run, short-run relationship between financial development and economic growth in Kenya. It also investigated the direction of causality between economic growth and financial development using time series over the period 1980-2011.

\section{Literature Review}

Several studies have been done to determine the causal relationship between financial development and economic growth. The studies range from cross country to country specific, using cross-section data and some using time series data. The studies have also used various proxies for financial development and different methodologies. So far the results are not conclusive.

The pioneering study on cross country analysis was done by Goldsmith (1969) where he carried out a study on 35 countries, using data for the period 1860-1963. The study used the ratio of financial intermediary assets divided by Gross Domestic Product (GDP) as a proxy for financial development and found that a positive relationship between financial intermediaries' assets and economic growth exists. In addition it also found that the size of financial intermediaries grew as countries continued to develop.

In addition to Goldsmith (1969), King and Levine (1993) investigated the relationship between financial development and economic growth on several countries (77) using data for 1960-1989. Unlike other studies, this study used several indicators for economic growth (real per capita GDP growth, total productivity growth and growth in capital stock per person) and several proxies for financial development. The proxies used for financial development included the ratio of liquid liabilities of the financial system, to GDP, which measures the depth of the financial sector and bank credit divided by bank credit plus central bank domestic assets which measures the allocation of credit, done by the commercial banks and central bank. The last indicator for financial development used is the ratio of private credit to enterprises to GDP. King and Levine (1993), found a positive relationship between financial development and economic growth. The study also found that financial development predicts economic growth, but failed to give clear information on the direction of causality.

In the same pursuit, Allen and Ndikumana (2000) using time series for Southern Africa investigated the role of financial intermediation in stimulating economic growth. The study used several indicators for financial development which are private credit, credit by banks, the ratio of M3 to GDP and an index for financial development, which combined the three indicators. It also included trade openness, government consumption and debt service as other control variables. In its results, the study found a positive and significant relationship between economic growth and liquid liabilities of banks. The results were not statistically significant for the other indicators (credit by banks, credit to the private sector and the overall index) of financial development.

The relationship between economic growth and financial development of selected Sub-Saharan countries was also investigated by Ndebbio (2004). The study used the ratio of M2 to GDP and growth rate of real money balances as indicators for financial development and found a statistically positive effect of growth of per capita real money balances on .economic growth.

Chistopoulos and Tsionas (2004), using panel data, of 10 developing countries, examined the relationship between financial development and economic growth .Their study used the ratio of bank deposit liabilities to nominal GDP as a measure of financial debt; it also included inflation rate and the ratio of investment to GDP as control variables. The results provided evidence of long-run unidirectional causality running from financial development to economic growth. However, the study did not find direction of causality between financial development and economic growth in the short-run.

Songul, IIhan, and Ali (2009) investigated the causality between financial development and economic growth in Sub- Saharan Africa for the period 1975-2005. The study used panel co-integration and panel GMM for causality analysis. The results from panel co-integration suggested that there is no long-run relationship between financial development and economic growth. Results on causality analysis indicated existence of bi-directional 
causality between financial development (credit to the private sector was used as proxy for financial development) and real GDP per capita. The study therefore, supports both the supply leading and demand following hypothesis

Mohd (2012) added a perspective by investigating the causal relationship between the developments of non-bank financial intermediaries (NBFIs) of Malaysia, using data for the period 1974-2004. The study used Autoregressive Distributed lag bounds test to investigate co-integration and granger causality test to determine the direction of relationship between development of non-bank financial intermediaries and per capita economic growth. The study found causality running from the development of non-bank financial intermediaries to per capita economic growth. The study also found that there existed, in long-run, a relationship between NBFIs and economic growth when economic growth acts as a dependent variable in the function; it found no long-run relationship when other variables appeared as dependent variables.

Mohsen and Maysam (2012) carried out a study on the relationship among financial development, energy consumption and economic growth in Iran using the data for the period 1970-2009. The ARDL bounds test for co-integration analysis and short-run dynamics among the variables was applied. The results of the study found co-integration to exist among real GDP, energy consumption, capital stock, oil revenues and credit to the private sector (a proxy for financial development). The study also found that capital stock level and financial development were the main engines of economic growth of Iran.

Rachdi and Mbarek (2011), using panel data co-integration and GMM system approach investigated the direction of relationship between finance and economic growth for 10 countries ( 6 for OECD and 4 for MENA (Middle East and North Africa countries). Their empirical results showed that there is cointegration between financial development and economic growth for OECD and MENA countries. In addition, the GMM system results confirmed that financial development and real GDP per capita are positively and strongly correlated. Lastly, the study also found that causality is bi-directional in OECD countries while for MENA countries are unidirectional, with economic growth causing financial development.

Muhammad and Muhammad (2010) investigated the direction of causality between financial development and economic growth, and co-integration among the two variables in Pakistan. The results of the study proved the existence of demand following hypothesis Pakistan, implying that economic growth granger causes financial development when broad money (M2) is used as a proxy variable for financial development. The study also found a long-run relationship between financial development and economic growth.

Atif,Jadoon,Zaman, Ismal and Seemad (2010) examined the impact of financial development and trade openness on GDP growth in Pakistan using annual data over the period 1980-2009. The study used the ARDL bound test by Pasaran et al. (2001). It found evidence of long-run relationship among the variables financial development, trade openness and economic growth. The study also found that FD and trade openness to Granger cause economic growth over the period of study.

Akinlo and Egbetunde (2010), investigated co-integration and the direction of causality between financial development and economic growth of ten sub- Saharan African countries. The study found that there is long-run relationship between financial development and economic growth in the countries selected. The results also showed that financial development granger causes economic growth in some countries while in others there was bi-directional causality between the two variables.

Odhiambo (2008), using time series of the period 1968-2002 and a dynamic causality model investigated causality between financial development and economic growth in Kenya. The study used broad money (M2), currency ratio $(\mathrm{CC} / \mathrm{M} 1)$ and credit to private sector as proxies of financial development. The results suggested that causality between financial development and economic growth depends on the proxy used for financial development in Kenya, and that causality on the balance runs from economic growth to financial development. This study supports the demand -following hypothesis on average.

Thus, it is clear from the literature review, regarding the relationship between financial development and economic growth, that studies produce mixed results. Most of the studies have found existence of long-run relationship between financial development and economic growth. The empirical results on the direction of causality are more mixed as compared to co-integration analysis. Some findings indicate that there is unidirectional causality running from financial development to economic growth, hence supporting supply leading hypothesis. Another variation in the results of causality is the finding of unidirectional causality running from economic growth to financial development; this supports the demand following hypothesis. 


\section{Data and Methodology}

The main objective of this paper was to investigate the dynamics of the relationship between financial development and economic growth using time series data over the period 1980-2011. The data was obtained from Kenya Economic survey (various years), Kenya`s Statistical Abstract (various years), Central Bank of Kenya`s annual supervision reports, and International Financial Statistics published by IMF.

There are several indicators of financial development that have been proposed in the literature. Similarly several studies have used various proxies for financial development. It is clear that from the definition of financial development, there is no single indicator which can measure financial development of a country. This paper uses the variable 1(ratio of $m 2$ to nominal GDP ( $m 2 / \mathrm{GDP}$ ) ) and ( ratio of domestic credit supplied to the private sector to nominal GDP $(p c r d / G D P)$ variable 2 as proxies for financial development.

The ratio of broad money supply $(\mathrm{m} 2)$ to nominal GDP, measures financial depth and the size of financial intermediation and shows expansion of payment and savings activities offered by the financial sector.

The proxy $p c r d /$ GDP is for financial depth; this ratio excludes the public sector and shows how credit is allocated more efficiently since the private sector utilizes funds more efficiently as compared to the public sector. The level of credit supplied to the private sector, indicates the working of the savings - investment channel done by the financial sector. Thus, an increase of this ratio shows how the financial sector allocates the savings received by the financial intermediaries to the private sector. A high ratio means that funds are available to the private sector to finance their investment activities. It is notable that developed financial sector channels funds to high return projects, hence impacting positively on economic growth. Therefore, financial development indicated by increase of credit to the private sector stimulates private investment in the country which in turn increases economic growth, holding other factors constant (King \& Levine, 1993). Lastly, real GDP per capita (y) was used as a proxy for economic growth.

The study also included trade openness of the economy as a control variable in income determination. It was included to account for the effects of international trade on economic growth of Kenya. Trade openness was measured by the ratio of the sum of the values of exports and imports to nominal GDP over the sample period. Usually, exports have the potential of impacting positively on economic growth if they increase demand for domestically produced goods in the international market, and are able to generate enough foreign exchange to finance capital imports (Allen \& Ndikumana, 2000). In addition, imports also stimulate economic growth if they mainly comprise of capital goods which are inputs in the production processes of the country. Notwithstanding, imports can also lead to decline of national income. This usually occurs when imports displace domestic production of goods and services. Total output of the country will drop as well as total employment which negatively affects national income.Thus, the combined effect of exports and imports can either be negative or positive. The exact effect can be determined empirically.

It is worth pointing out that all variables were transformed to natural logarithms before analysis to avoid the problem of heteroscedasticity of the error terms; the estimated coefficients on level variables are elasticities. Since all variables were found to be non-stationary, they were differenced once and the estimated parameters of first differences of the natural logarithms gave approximate growth rates of the variables

In addition, this study used the Autoregressive Distributed Lag (ARDL) bounds testing approach to estimate the short and long-run relationships among the variables. This method was developed by Pesaran and Pesaran (1997), Pesaran and Shin (1999) Pesaran et al. (2001). The method has several advantages; as opposed to other multivariate co-integration methods such as Johansen and Juselius (1990), it allows the co-integration relationship to be estimated by OLS once the lag order of the model is identified. This method is applicable whether the regressors are I (0), I (1) or mutually co-integrated. Therefore, it doesn't require the pretesting of the variables included in the model for unit roots unlike other techniques such as Johansen approach. It is relatively more efficient in small or finite sample data sizes. Additionally, the estimates derived from Johansen- Juselius method of co-integration are not robust when subjected to small sample sizes (Loesse, 2009; Narayan, 2005; Pattichis, 1999; Mah, 2000; Tang \& Nair, 2002). Also, a dynamic unrestricted error correction model (UECM) can be derived from the ARDL bounds testing model through a simple linear reparametrization. Thus, the UECM combines the short-run dynamics with the long-run equilibrium without losing any long-run information.

There are four steps in the ARDL testing. Foremost, even if as mentioned above the method does not need pre-testing for stationarity of the variables, it was still necessary to conduct unit root tests. This is because the ARDL test fails for variables which are above I (1).

The second stage was to check for a long-run relationship among the variables using the following model (1). 


$$
\begin{aligned}
& \Delta L n y_{t}=\lambda_{0}+\sum_{i=1}^{k} \theta_{i} \Delta L n y_{t-i}+\sum_{i=0}^{k} \delta_{i} \Delta \operatorname{Lnfd}_{t-i}+\sum_{i=0}^{k} \pi_{i} \Delta \operatorname{Lnop}_{t-i}+\beta_{4} L n y_{t-1}+ \\
& \beta_{5} \operatorname{Lnfd}_{t-1}+\beta_{6} \text { Lnop }_{t-1}+u_{t}
\end{aligned}
$$

Where $\Delta$ is the first difference operator; y represents real GDP per capita a proxy variable for economic growth; fd represents financial development; op represents trade openness of the economy; $t$ represents time; Ln stands for natural logarithms; $\mathrm{k}$ is the lag length and $\mathrm{u}$ is the error term assumed to be serially uncorrelated. The parameters $\theta_{\mathrm{i}}, \delta_{\mathrm{i}}, \pi_{\mathrm{i}}$ are the short-run dynamic coefficients of the ARDL model while $\beta_{4}, \beta_{5}$, and $\beta_{6}$ are long-run parameters (elasticities).

Co-integration among the variables was investigated by testing the null hypothesis of no co-integration H0: $\beta_{\mathrm{i}}=$ 0 , against the alternative hypothesis $\mathrm{H}_{1}: \beta_{\mathrm{i}} \neq 0$ of the existence of co-integration. The existence of co-integration is tested by the F-test of the joint significance of the long-run coefficients.

Pesaran et al. (2001), provides critical values, upper and lower critical values which have to be compared with the F-statistic in order to accept or reject the null hypothesis. The lower critical values assume all the variables are I (0) while the upper critical value assumes all the variables are I (1). If the variables are I (2) or above the ARDL bounds test is inapplicable. If the F-statistic exceeds the upper critical bound, the null hypothesis is rejected meaning that there is co-integration among the variables. Likewise, if the F- statistic is below the lower critical bound; the null hypothesis is accepted indicating there is no long-run relationship among the variables. However, if the F- statistic falls within the band, the result is inconclusive but, if all variables are known to be $\mathrm{I}(1)$, a decision is made using the upper critical values, and if all are known to be $\mathrm{I}(0)$, a decision is made using the lower critical values.

To generate the critical values Pesaran et al. (2001) used huge sample sizes of 500 and 1000 and 20,000 and 40,000 replications, respectively. Narayan (2004) argue that such critical values are not applicable for small samples such as the sample size for this study (31). In this study I used the critical values by Narayan (2004) which are applicable for smaller sample sizes of 30 to 80 .

If long-run relationship is established among the variables in model 1, the next step was to construct an optimal ARDL specification of model 1. The AIC was used to select the optimal lag length. A general ARDL model is of the following form:

$$
L n y_{t}=\delta_{0}+\sum_{i=1}^{k} \lambda_{i} L n y_{t-i}+\sum_{j=0}^{k} \delta_{1 j} \operatorname{Lnfd}_{t-i}+\sum_{i=0}^{k} \delta_{2 i} \text { Lnop }_{t-i}+u_{t}
$$

The above model was also estimated by use of OLS. The long run coefficients were estimated by use of the following formula:

The estimated equation is used to obtain the Error Correction term $\left(\mathrm{ECT}_{\mathrm{t}-1}\right.$ which is later used in the Error correction model (ECM). If co-integration is confirmed then the next step was to investigate short-run dynamics by estimating the vector error correction model (VECM) derived from ARDL model. Existence of co-integration suggests that there is Granger causality in at least one direction, but does not indicate the direction of causality. This needed to be investigated of the direction of causality between $f d$ and $y$. The VECM is represented by the following equation:

$$
\begin{aligned}
& \Delta L n y_{t}=\varphi_{0}+\sum_{i=1}^{k} \varphi_{i} \Delta L n y_{t-i}+\sum_{j=0}^{n} \beta_{i} \Delta L n f d_{t-i}+\sum_{i=0}^{m} o_{i} \Delta L n o p_{t-i}+\delta_{i} E C T_{i t-1}+u_{1 t} \\
& \Delta L n f d_{t}=\phi_{0}+\sum_{i=1}^{k} \phi_{i} \Delta L n f d_{t-i}+\sum_{j=0}^{n} \tau_{i} \Delta L n y_{t-i}+\sum_{i=0}^{m} \pi_{i} \Delta L n o p_{t-i}+\alpha_{i} E C T_{i t-1}+u_{2 t}
\end{aligned}
$$

Where, $\Delta$ is the first difference operator while $\Delta \operatorname{Ln} y_{\mathrm{t}-\mathrm{i}}, \Delta \operatorname{Ln} f d_{\mathrm{t}-\mathrm{I}}$ and $\Delta \operatorname{Ln} o p_{t-\mathrm{I}}$ captures the short-run dynamics of the model; Ut's are the error term assumed to be uncorrelated; $\mathrm{ECT}_{\mathrm{it}-1}$ are error correction terms obtained from equation 2. It is notable that the coefficients of the ECT ( $\delta$ and $\alpha$ ) captures adjustment towards long-run equilibrium; this coefficient must be negative and statistically significant. The negative sign means that the dependent variable $(y)$ adjusts back to its equilibrium value following a shock in the short-run. The magnitude of the coefficient measures the speed of adjustment of any disequilibrium caused by short-run shocks of the 
previous period towards long-run value. Thus, the larger the ECT coefficient, the higher is the speed of adjustment of the model from short-run to the long- run.

In addition, the ECT also represents long-run relationship with negative and statistically coefficient of ECT giving evidence of long- run causal relationship. If both coefficients of the ECTs in the two equations 4 and 5 are statistically significant, there will be evidence of the existence of bi-directional causality between economic growth and financial development. However, if only $\delta$ is negative and significant it shows unidirectional causality running from $f d$ to economic growth. Additionally, if $\alpha$ is negative and significant, it indicates bi-directional causality running from economic growth to financial development. However, if none of the coefficients is statistically significant, then there is no causality between $f d$ and economic growth.

\section{Empirical Results}

\subsection{Descriptive Statistics}

Table 1 shows correlation analysis among the variables in the model. From the coefficients, the results show that all the variables are positively correlated, except with trade openness. The strongest association was found to be between $m 2$ and pcrd (0.94), suggesting that they are can be used as substitutes. The two financial development indicators $m 2$ and $p c r d$ are each moderately positively correlated to $y(0.67$ and 0.72$)$. The relationship between trade openness and all variables is consistently negative, suggesting a negative impact of trade openness on all variables in the model.

Table 1. Correlation matrix among the variables (All variables are in natural logarithms)

\begin{tabular}{lllll}
\hline & $\boldsymbol{m} \mathbf{2}$ & pcrd & $\boldsymbol{y}$ & $\boldsymbol{o p}$ \\
\hline $\boldsymbol{m} \mathbf{2}$ & 1.00 & & & \\
$\boldsymbol{p} \boldsymbol{c r d}$ & 0.94 & 1.00 & & \\
$\boldsymbol{y}$ & 0.67 & 0.72 & 1.00 & \\
$\boldsymbol{o p}$ & -0.53 & -0.54 & -0.48 & 1 \\
\hline
\end{tabular}

\subsection{Unit Root Test}

The bounds test approach to co-integration does not need pre-testing for stationarity of the variables included in the model, but still it is important to carry out stationarity tests on all the series. This is because the ARDL bounds test to co-integration is not applicable if the order of integration is above I(1). It was therefore, necessary to test for stationarity of the variables before regression analysis was done. It is notable that stationarity properties of time series are investigated by testing for unit roots and there are several methods for testing for stationarity. Thus, this study used the commonly used Augmented Dickey Fuller (ADF) (1981) and the PhillipsPerron (PP) Phillips and Perron (1988) unit root tests. The unit root tests results are presented in Table 2.

Table 2. Augmented dickey fuller and phillips-perron unit root test results

\begin{tabular}{lllll}
\hline Variable & & ADF & PP \\
& Level & First Difference & Level & First Difference \\
\hline$P C R D$ & $-1.46(1)$ & $-4.84(1)^{* * *}$ & -1.88 & $-4.99^{* * *}$ \\
$M 2$ & $-3.14(3)$ & $-4.49(3)^{* * *}$ & -1.90 & $-4.60^{* * *}$ \\
$Y$ & $-2.18(1)$ & $-4.25(1)^{* * *}$ & -5.72 & $-4.25 * * *$ \\
$O P$ & $-1.98(1)$ & $-5.33(1)^{* * *}$ & -2.09 & $-5.75^{* * *}$ \\
\hline
\end{tabular}

Note. *** denote significance at $1 \%$. Figures in (.) represents lag length selected by AIC criterion. The PP length was selected by Newey-West Band Width.

Table 2, shows unit root results of the series at both level and first differences. Based on ADF test, all the series were found to be stationary at their first differences. The PP results support the ADF results; the results suggest that all the variables considered in this study are integrated of order one, I (1). Thus, with the establishment of the order of integration, the study proceeded to testing for long-run relationship expressed in equation 2 .

\subsection{Co-Integration Results}

The first step of the ARDL bounds analysis is to investigate presence of long-run relation among the variables included in model 1. The model was estimated by OLS for each proxy for financial development and the optimal lag was selected by Akaike Information criterion (AIC) method and Schwarz Bayesian Information criterion 
(SBC). After estimation the authorconducted an F-test on joint significance of the lagged variables in levels. The results of the F-test for both $M 2$ and PCRD proxies for FD respectively are presented in Table3. The table also provides the upper and lower Narayan (2004) critical values.

Table 3. Bounds F-tests for a cointegration relationship

\begin{tabular}{lllll}
\hline $\mathbf{k}$ & F-statistics & Level of significance & Lower Critical values & Upper critical values \\
\hline 2(independent variables: & $\mathbf{5 . 1 6 * *}$ & $1 \%$ & 5.075 & 6.24 \\
$\mathrm{M}_{2}$, OP & & $5 \%$ & 3.535 & 4.653 \\
& & $10 \%$ & 2.890 & 3.800 \\
2(Independent variables: & $\mathbf{4 . 1 0 2 *}$ & $1 \%$ & 5.075 & 6.24 \\
PCRD, OP) & & $5 \%$ & 3.535 & 4.653 \\
& & $10 \%$ & 2.890 & 3.800 \\
\hline
\end{tabular}

Note. $* *$ represents statistical significance at $5 \%$ level, * represents statistical significance at $10 \%$.Critical values were obtained from Narayan (2004) for the case of restricted intercept and no trend. K stands for number of independent variables in the model.

The F-statistics were compared with the upper and lower bound Narayan (2004) critical values. According to the results displayed in Table 3, the F-Statistics (5.16) of the equation, when M2 is used as a proxy for FD and GDP is the dependent variable, is greater than the 5\% upper bounds critical values of Narayan (2004). This means rejecting the null hypothesis of no co-integration. Therefore, the results indicate that there is evidence of long-run relationship among the variables GDP, M2, and trade openness of the Kenyan economy.

In addition, the results for the same equation when PCRD is used as a proxy for FD and GDP is used as dependent variable, the F-statistics (4.102) also exceeds the upper Narayan (2004) bounds 10\% critical value. This suggests the existence of long run relationship among the variables Y, PCRD, and trade openness of the economy. Both equations passed all diagnostic tests. From both results there is evidence of long-run relation among economic growth, financial development and openness of the economy. These results are similar to many previous studies (Mohsen \& Maysam, 2012; Rachdi \& Mbarek, 2011; Muhammad \& Muhammad, 2010; Atif et al., 2010; Mohd, 2012). The two models passed all the diagnostic tests for autocorrelation, normality, functional form and heteroscedasticity.

\subsection{Long-Run Estimates}

Table 4. Long-run estimated results, dependent variable LnYt, independent variables, LnM2/Y, LnOP/Y

\begin{tabular}{lllllll}
\hline Variable & coefficient & t- Statistic & P-value & Long-run coefficients & \multicolumn{2}{l}{ Diagnostic Tests } \\
\hline $\mathrm{C}$ & 0.354 & 1.9 & 0.073 & $\mathbf{2 2 . 1 2 5}$ & $\mathrm{R}^{2}$ & 0.99 \\
$\mathrm{Y}(-1)$ & $0.802^{* * *}$ & 3.7 & 0.001 & & Adj R & 0.99 \\
$\mathrm{Y}(-2)$ & -0.040 & -0.13 & 0.896 & & D.W & 2.13 \\
$\mathrm{Y}(-3)$ & 0.222 & 1.05 & 0.304 & & J.B & $6.2(0.05)$ \\
M2 & $0.250^{* *}$ & 2.18 & 0.040 & $\mathbf{4 . 6 2 6}$ & B.G & $3.5(0.04)$ \\
M2(-1) & -0.176 & -1.58 & 0.129 & & Ramsey RESET & $0.17(0.68)$ \\
OP & -0.020 & -0.80 & 0.430 & $\mathbf{- 1 . 2 5}$ & ARCH & $0.114(0.73)$ \\
\hline
\end{tabular}

Note. The asterisks ***,** shows significance at $1 \%$ and $5 \%$ respectively.

The empirical results of long-run coefficients shows that broad money (M2), as expected, has a positive (4.626) effect on economic growth, while openness has a negative (-1.25) effect on economic growth. Based on the results, economic growth in Kenya is financial development elastic when $M 2$ is used as a proxy for financial development. The long-run M2 elasticity in the ARDL model is 4.626 and is statistically significant at 5 per cent. This means that, a one per cent increase in $M 2$ leads to 4.63 per cent increase in GDP. This result agrees to the findings of Muhammad and Umer (2010) and King and Levine (1993). It also notable that an increase in trade openness leads to reduction of economic growth in Kenya as shown by the negative coefficient; a one per cent increase in trade openness of the Kenyan economy GDP declines by 1.25 per cent. This negative effect is explained by the fact that imports were consistently above the value of exports over the sample period. According to the results, economic growth is openness elastic. However, this result is not statistically significant indicating that openness does not have an important effect on economic growth in Kenya. Nonetheless, the 
model passed all the diagnostic tests. Table 5 shows long-run results when the dependent variable is M2.

Table 5. Long-run Coefficients when dependent variable is Ln M2, Independent variables LnY, and LnOP

\begin{tabular}{llllllc}
\hline Variable & coefficient & t- Statistic & P-value & Long-run coefficients & \multicolumn{2}{l}{ Diagnostic Tests } \\
\hline C & -0.55 & -2.045 & 0.052 & $\mathbf{- 2 . 7 5}$ & $\mathrm{R}^{2}$ & $0.88 ;$ \\
M2(-1) & $0.91^{* * *}$ & 5.052 & 0.000 & & Adj R & 0.85 \\
M2(-2) & -0.11 & -0.649 & 0.520 & & D.W & $2.02 ;$ \\
Y & $0.71^{* *}$ & 2.258 & 0.033 & $\mathbf{0 . 1 5}$ & J.B & 4.3 \\
$Y(-1)$ & $-0.68^{* *}$ & -2.166 & 0.041 & & B.G & $\mathrm{F}=0.4(0.65)$ \\
OP & -0.04 & -1.015 & 0.320 & $\mathbf{- 0 . 2 0}$ & ARCH & $\mathrm{F}=0.56(0.45)$ \\
C & -0.55 & -2.045 & 0.052 & $\mathbf{- 2 . 7 5}$ & Ramsey RESET & $\mathrm{F}=2.63(0.12)$ \\
\hline
\end{tabular}

Note. ${ }^{* * *}, * *$ represents significant at 1 and 5 percent respectively.

Results in Table 5, shows that GDP has a positive impact on financial development proxied by $M 2 / G D P$. A one percent increase in GDP leads to 0.15 percent increase in financial development. This effect is statistically significant at five percent. Thus, increase in economic growth in the country, creates demand for financial services leading to the development of the financial sector. On the other hand, trade openness has a non-significant negative effect on financial development. The estimated model passes all diagnostic tests of normality, serial correlation, functional form, heteroscedasticity and stability tests.

Table 6 presents long-run results for the model 2 with PCRD/Y, OP/Y taking the position of independent variables and $\mathrm{Y}$ the dependent variable.

Table 6. Long-run estimated results dependent variable $\mathrm{LnY}$, independent variables $\operatorname{Ln} P C R D / \mathrm{GDP}$, LnOP/GDP

\begin{tabular}{lllllll}
\hline Variable & coefficient & t- Statistic & P-value & Long-run coefficients & \multicolumn{2}{c}{ Diagnostic Tests } \\
\hline $\mathrm{C}$ & 0.339 & 1.9 & 0.073 & $\mathbf{1 . 5 7 7}$ & $\mathrm{R}^{2}$ & $0.99 ;$ \\
$Y(-1)$ & $0.938^{* * *}$ & 4.33 & 0.000 & & Adj R $^{2}$ & 0.99 \\
$Y(-2)$ & -0.220 & -0.73 & 0.48 & & D.W & $2.0 ;$ \\
$Y(-3)$ & 0.267 & 1.24 & .225 & & J.B & $2.28(0.3)$ \\
$P C R D$ & 0.054 & 1.14 & 0.277 & $\mathbf{0 . 2 5 1}$ & Ramsey RESET & $0.07(0.8)$ \\
$O P$ & -0.024 & -.93 & 0.36 & $\mathbf{- 0 . 1 1 1}$ & ARCH & $0.134(0.73)$ \\
$\mathrm{C}$ & 0.339 & 1.9 & 0.073 & $\mathbf{1 . 5 7 7}$ & & \\
\hline
\end{tabular}

Note. $* * *$ shows that it is significant at $1 \%$.

Based on the empirical results in Table 6, the coefficient of private credit is consistent with theoretical expectation. The private credit in Kenya has a positive effect on economic growth; a one per cent increase in private credit leads to increase of economic growth by 0.25 per cent. However, this result is not statistically significant and just like the previous result, increase of openness of Kenyan economy declines economic growth by 0.11 per cent. Thus, the government needs to implement policies that will reduce imports and increase the revenue received from exports, for openness to have a positive impact on economic growth. The estimated model passed all the basic diagnostic tests of normality, stability of coefficients, serial correlation, heteroskedasticity, and functional form.

Table 7, shows long-run estimated coefficients when PCRD takes the position of dependent variable, and LnOP, and $\mathrm{LnY}$ are independent variables.

Table 7. Long-run estimated model. Dependent variable: PCRD, independent variables LnY, LnOP/GDP

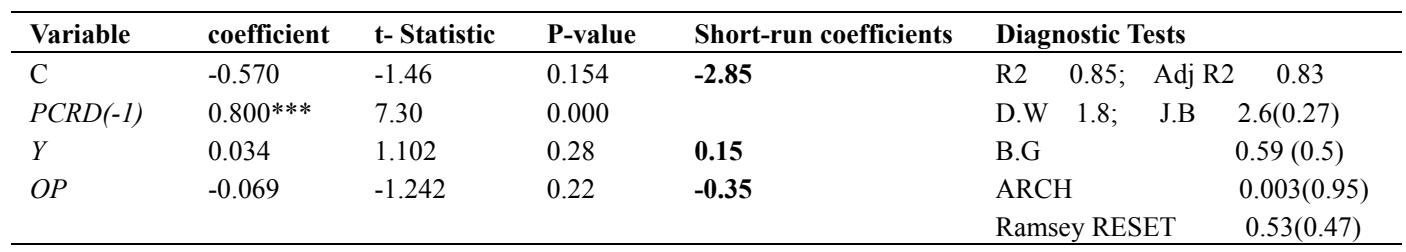

Results in Table 7, shows that $Y$ has positive impact on financial development as proxied by domestic credit to 
the private sector. A one percent increase in $Y$ leads to 0.15 percent increase in domestic credit to the private sector. However, this impact is statistically non-significant. Just like other models, trade openness has a non-significant negative effect on domestic credit to the private sector. Nevertheless, the estimated model passed all diagnostic tests.

\subsection{Short-Run Dynamics}

Since the ARDL bounds test showed that the variables, GDP, FD and trade openness are co-integrated, we then are justified to use Error Correction model (ECM) to investigate the short-run dynamics based on ARDL approach as expressed in equations 3 and 4 . The error correction model provides information of partial adjustment and allows for estimation of short-run elasticities. Table 8, shows the empirical results for the ECM, when $M 2$ is used as a proxy for financial development.

Table 8. Error correction results, dependent variable $\triangle$ Ln Y independent variables $\triangle$ Ln (M2), $\triangle$ (Ln op)

\begin{tabular}{|c|c|c|c|c|c|c|c|}
\hline variable & coefficient & t-statistics & $\mathrm{p}$-value & Short-run Coefficients & \multicolumn{3}{|c|}{ Diagnostic Tests } \\
\hline $\mathrm{c}$ & 0.048 & 1.168 & 0.25 & 0.102 & $\mathrm{R}^{2}$ & 0.38 & $\operatorname{Adj} R^{2} \quad 0.23$ \\
\hline $\mathrm{D}(Y(-1)$ & -0.186 & -0.957 & 0.35 & & D.W & 2.2 & J.B $0.49(0.78)$ \\
\hline $\mathrm{D}(Y(-2)$ & $0.717 *$ & 1.92 & 0.068 & & B.G & & 0.64 \\
\hline $\mathrm{D}(M 2)$ & $0.207 * *$ & 2.079 & 0.05 & 0.141 & $\mathrm{ARCH}$ & 0.167 & $(0.68)$ \\
\hline $\mathrm{D}(O P)$ & -0.003 & -0.10 & 0.92 & -0.006 & Rams & RESET & $1.8(0.19)$ \\
\hline $\operatorname{ECTm} 2(-1)$ & $-1.2^{* * *}$ & -2.64 & 0.015 & & & & \\
\hline
\end{tabular}

Note. $* * * * *$, and $*$ shows significance at $1 \%, 5 \%$ and $10 \%$, respectively.

In the short-run, the coefficient of $f d$ has the expected sign (positive). Based on the results, if $f d$ as proxied by $M 2$, increase by one percent income will increase by 0.141 per cent in the short-run. This result is statistically significant at 5 per cent. However, the short- run trade openness elasticity is negative just as the long -run. Thus, if Kenyan openness increases by one per cent, economic growth will decline by 0.006 per cent. This result is still statistically insignificant.

The coefficient of the ECT in the Error correction model shows the speed of adjustment towards long-run equilibrium following a shock to the system. The coefficient of ECT should have a statistically negative sign. According to the results in table 8, the ECT is negative (-1.2) as expected showing that the adjustment is towards the right direction to restore long-run equilibrium. The coefficient of ECT is statistically significant at $1 \%$; this shows that the deviation of GDP from equilibrium values is corrected by $120 \%$ in the following year. The adjustment towards equilibrium takes place very quickly. Hence, the significant ECT confirms the existence of long-run equilibrium relationship among $Y, M 2$ and trade openness of the economy as well.

In addition, the coefficient of the ECT which is statistically significant also provides evidence of existence of unidirectional Granger causality running from financial development to economic growth. This result supports the supply leading hypothesis meaning that growth follows financial development in Kenya.

The estimated model passed all the diagnostic tests as shown in the bottom part of the table.

Table 9. ECM results, dependent variable $\triangle \mathrm{LnM}$, independent variables, $\triangle \mathrm{LnY}, \triangle \mathrm{OP}$

\begin{tabular}{lllllll}
\hline variable & Coefficient & t-statistics & p-value & Short-run Coefficients & Diagnostic Tests \\
\hline C & -0.076 & -2.19 & 0.04 & $\mathbf{1 . 1 9}$ & $\mathrm{R}^{2}$ & 0.52 \\
M2(-1) & $0.716^{* *}$ & 2.611 & 0.016 & & Adj R $^{2}$ & 0.38 \\
M2(-2) & -0.057 & -0.350 & 0.730 & & D.W & 1.8 \\
M2(-3) & $0.405^{* * *}$ & 2.743 & 0.012 & & J.B & $6.33(0.04)$ \\
Y & $0.755^{* *}$ & 2.589 & 0.017 & $\mathbf{- 1 1 . 7 9}$ & B.G & $1.5(0.3) ;$ \\
OP & -0.0144 & -0.295 & 0.770 & $\mathbf{0 . 2 2 5}$ & ARCH & $0.74(0.4)$ \\
ECTm2(-1) & $-0.961^{* * *}$ & -3.033 & 0.006 & & Ramsey RESET & $1.75(0.18)$ \\
\hline
\end{tabular}

Note. ${ }^{* *},{ }^{* *}$ shows significant at $1 \%$ and $5 \%$ respectively.

The results in table for the ECM, when the dependent variable is $M 2$ show that $Y$ has a negative effect on $M 2$ in the short-run; a one percent increases in Y leads to approximately 12 percent decline in $M 2$ in the short-run. This 
effect is statistically significant at 5 percent. Consequently, trade openness has a positive effect on financial development in the short-run. This effect, just like the rest above, is statistically not significant. Additionally, the coefficient of ECT as expected, has a negative sign which is highly significant at 1 percent; the result shows that 96 percent of disequilibria from the previous year`s shock converge back to the long-run equilibrium in the current year. Also the magnitude of the ECT coefficient (-0.961) shows that the speed of adjustment towards long-run equilibrium is very fast. Lastly, the significant coefficient of the ECT also confirms the existence of long-run relationship among $Y, M 2$ and $o p$.

It can thus be stated that the coefficient of the ECT, which is statistically significant, suggests that there is Granger unidirectional causality running from economic growth to financial development. This means financial development follows economic growth in Kenya which supports demand following hypothesis. It is however notable that the estimated model passed all diagnostic tests of normality, autocorrelation, functional form and heteroscedasticity and the estimated parameters were stable over the study period.

The following Table 10 presents short- run results when $\triangle \mathrm{Ln} \mathrm{Y}$ is the dependent variables and PCRD is used as a proxy for FD.

Table 10. Results for error correction model dependent variable $\triangle \mathrm{LnY}$, independent variables: PCRD, Ln OP

\begin{tabular}{|c|c|c|c|c|c|c|}
\hline variable & Coefficient & t-statistics & p-value & Short-run Coefficients & Diagnostic Tests & \\
\hline $\mathrm{C}$ & 0.019 & 0.315 & 0.755 & 0.026 & $\mathrm{R}^{2}$ & 0.36 \\
\hline DY(-1) & -0.234 & -1.070 & 0.297 & & Adj $R^{2}$ & 0.12 \\
\hline DY(-2) & $1.226 * *$ & 2.027 & 0.056 & & D.W & 2.3 \\
\hline DY(-3) & -0.255 & -1.208 & 0.242 & & J.B & $1.14(0.56)$ \\
\hline DPCRD & $0.152 *$ & 1.925 & 0.07 & 0.452 & B.G & $1.35(0.28)$ \\
\hline $\operatorname{DPCRD}(-1)$ & $0.181 * *$ & 2.143 & 0.05 & & Ramsey RESET & $4.32(0.05)$ \\
\hline DOP & 0.009 & 0.289 & 0.78 & 0.012 & $\mathrm{ARCH}$ & $0.005(0.93)$ \\
\hline ECTcrd(-1) & $-1.4 * *$ & -2.585 & 0.02 & & & \\
\hline
\end{tabular}

It is imperative to note that the short-run coefficients are consistent with theoretical expectations; in the short-run both private credit and openness of Kenyan economy have positive effect on economic growth and economic growth is inelastic in both private credit and trade openness of the economy. One per cent increase in private credit leads to about 0.45 per cent increase in economic growth in the short-run. This result is statistically significant at five per cent. Thus, if Kenyan trade openness increases by one per cent, economic growth will increase by 0.012 in the short-run; this result is statistically insignificant.

However, the ECT is negative as expected and is statistically significant at five per cent. About $100 \%$ of the previous year's deviation from equilibrium is corrected within the next year and this result also confirms the existence of long-run equilibrium relationship among $Y, P C R D$ and $O P$. On the other hand, the coefficient of ECT which is negative and statistically significant shows that there is unidirectional causality running from financial development to economic growth; this is when domestic credit to the private sector is used as a proxy for financial development. This finding confirms supply leading hypothesis that financial development Granger causes economic growth in Kenya. It is also notable that the short-run results passed all the diagnostic tests of normality, serial correlation, functional form and heteroskedasticity. In addition, the results in Table11 presents short-run results; this is when the ratio of domestic credit to the private sector to $\mathrm{Y}$ is the dependent variable while the rest of the variables are independent variables, expressed in their first differences.

Table 11. ECM results, dependent variable $\triangle \mathrm{PCRD}$, independent variables $\triangle \mathrm{LnY}, \triangle \mathrm{Ln}$ OP

\begin{tabular}{lllllll}
\hline Variable & Coefficient & t-Statistics & p. value & Short-run coefficients & Diagnostic Tests \\
\hline C & -0.067 & -1.15 & 0.26 & $\mathbf{0 . 0 8 9}$ & $\mathrm{R}^{2}$ & 0.34 \\
$P C R D(-1)$ & $1.079^{* *}$ & 2.17 & 0.04 & & Adj $^{2}$ & 0.15 \\
$P C R D(-2)$ & 0.259 & 1.33 & 0.20 & & D.W & 2.0 \\
$P C R D(-3)$ & $0.413^{* *}$ & 2.095 & 0.05 & & J.B & $8.9(0.01)$ \\
Y & 0.475 & 0.970 & 0.34 & $\mathbf{- 0 . 6 3 2}$ & B.G & $2.3(0.126)$ \\
OP & -0.082 & -1.018 & 0.32 & $\mathbf{0 . 1 0 9}$ & ARCH & $0.5(0.48)$ \\
ECTcrd(-1) & $-1.3^{* *}$ & -2.57 & 0.017 & & Ramsey RESET & $0.39(0.5)$ \\
\hline
\end{tabular}

Note. ** Significant at 5 percent.

The results show that economic growth leads to a reduction in domestic private credit in the economy in the 
short-run; a one percent increase in GDP reduces growth in private credit by 0.63 percent in the short-run. However, this effect is statistically insignificant. Trade openness has a non-significant positive effect on changes in domestic private credit in the short-run. Notably, the coefficient of the ECT is negative (-1.3) as expected and it is statistically significant at five percent. The value of the ECT coefficient (-1.3) on the other hand, suggest a very high speed of adjustment towards long-run equilibrium after a short-run shock. The result suggests that, a deviation from long-run equilibrium following a shock is corrected by 130 percent in the following year. The coefficient of the ECT which is significant is another confirmation of the existence of long-run relationship among the variables economic growth, private domestic credit and trade openness in Kenya. In addition, the significant ECT coefficient also confirms that there is unidirectional causality running from economic growth to financial development. This result confirms that the demand following hypothesis is applicable in Kenya. Thus, economic growth Granger causes financial development. The estimated model passed all diagnostic tests as shown in the information in the lower extreme right of the table.

It is evident that from all the estimated results of the VECM that the empirical findings suggest that there is bi-directional causality between financial development and economic growth in Kenya in the period of study. These results agree with other previous studies of Songul et al (2009) that found bi-directional causality between financial development and economic growth for Sub-Saharan Africa and Rachdi and Mbarek (2011), whose findings confirmed existence of bi-directional causality for OECD countries. The results also agree with the findings of Akinlo and Egbetunde (2010) whose findings confirmed existence of bi-directional causality between financial development and economic growth in Kenya. However, these results do not agree with the findings of Odhiambo (2008). The variation of the findings of my study with Odhiambo's (2008), could be due to many financial developments which have taken place in Kenya between 1980 to 2011 such as growth of ATMs and setting up of many commercial branches.

The results therefore, support both the supply leading and demand following hypotheses in Kenya. This means that financial development accelerates and augments economic growth in Kenya and also that economic growth leads to development of the financial sector. It is therefore important for the country to implement policies and provide incentives that can develop this sector for faster economic growth to be achieved. On the other hand, faster economic growth creates demand for financial services which leads to the development of the financial sector. Financial development and economic growth in Kenya are complementary.

\section{Summary and Conclusion}

This paper examined the long-run, short-run and causality analysis between financial development and economic growth in Kenya. The study used the Autoregressive distributed lag (ARDL) bounds testing procedure developed by Pesaran et al. (2001) to examine the presence of long-run relationship among the variables, and the Vector Error Correction Model to investigate the short-run dynamics and direction of causality between the variables economic growth and financial development. Empirical results of stationarity analysis revealed that all the variables are I (1).

Empirical results showed that there is a significant long-run equilibrium relationship among financial development, economic growth and openness of the economy. The estimated F-Statistics (5.16 and 4.102) were above the upper Narayan (2004) critical values for both proxies of financial development acting as independent variables.The estimated long-run parameters indicated that financial development (when M2 was used as a proxy for financial development) has a significant positive (4.626) impact on economic growth while domestic private credit has a non- significant positive (0.251) impact on economic growth. When the financial development was used as a dependent variable, economic growth was found to have positive long-run effect on financial development. The estimated long-run elasticities with respect to economic growth when M2 and PCRD are used as dependent variables respectively were found to be approximately the same $(0.15)$. On the other hand, trade openness on average was found to have a no significant negative effect on financial development and economic growth. This is because the value of imports exceeds the value of exports in the sample period.

The coefficients of all ECTs in all VECMs were negative and statistically significant. This confirmed the existence of long-run relationship among the variables financial development, economic growth and trade openness. Since the ECT coefficients were significant, for both cases when economic growth and when financial development acted as dependent variables respectively, the researcher can conclude that there is bi-directional causality between financial development and economic growth in Kenya in the period under study. This result supports both the supply leading and demand following hypotheses.

Consequently, the results suggest that financial development is one of the determinants of economic growth in Kenya. It is therefore important for the government to implement policies and provide incentives for the 
continuation of development of the financial sector for growth of the economy. On the other hand, growth of the economy will create demand for financial services leading to development of the financial sector; economic growth and financial development are interdependent.

In addition, the results of this study are important to development policy makers; the policy makers can influence economic growth positively by setting both short-run and long-run policies that lead to the development of the financial sector. This may be in the form of increasing the number of financial institutions to enhance supply of credit to the private sector. It is notable that the development of the financial sector increases savings which feeds investment in the economy allocates resources efficiently, mitigates the problem of asymmetric information among other benefits. Consequently, the government should strengthen the reforms in the financial sector which can attract investors and improve the efficiency of all production activities in the country. All these, lead to economic growth in the long-run. In addition, implementing policies that lead to economic growth will in the short-run and long-run lead to the development of the financial sector. Thus, the government should enhance macro-economic policies especially the fiscal policies, policies that attract foreign direct investment, and export promotion policies that will on average, lead to economic growth. With economic growth, demand for financial services will increase, leading to the development of the financial sector.

\section{References}

Akinlo, A. E., \& Egbetunde, T. (2010). Financial development and economic growth: The experience of 10 Sub-Saharan African countries Revisited. The Review of Finance and Banking, 2(1), 17-28.

Alam, M. I., \& Quazi, R. M. (2003). Determinant of capital flight: an econometric case study of Bangladesh. International Review of Applied Economics, 17, 85-103. http://dx.doi.org/10.1080/713673164

Allen, D. S., \& Ndikumana, L. (2000). Financial intermediaries and economic growth in Southern Africa. Journal of African Economies, 9(2), 132-160. http://dx.doi.org/10.1093/jae/9.2.132

Ang, J. B. (2008). What are the mechanisms linking financial development and economic growth in Malaysia? Economic Modeling, 25, 38-53. http://dx.doi.org/10.1016/j.econmod.2007.04.006

Atif, R. M., Jadoon, A., Zaman, N. K., Ismail, A., \& Seemad, R. (2010). Trade liberalization, financial development and economic growth: Evidence from Pakistan (1980-2009). Journal of International Academic Research, 30-37.

CBK, CMA, IRA, RBA, SASRA. (2011). Kenya `s Financial sector Stability Report.

Central Bank of Kenya. (Various years). Bank Supervision Annual Report. Nairobi: Central Bank of Kenya press.

Cheung, Y., \& Lai, K. S. (1993). Finance sample sizes of Johansen`s likelihood ratio test for co-integration. Oxford Bulletin of Economics and Statistics, 55, 313-328. http://dx.doi.org/10.1111/j.1468-0084.1993.mp55003003.x

Choe, C., \& Moose, I. A. (1999). Financial system and economic growth: The Korean experience. World Development, 27(6), 1069-1082. http://dx.doi.org/10.1016/S0305-750X(99)00042-X

Christopoulos, D. K., \& Tsionas, E. G. (2004). Financial development and economic growth: Evidence from panel unit root and co-integration test. Journal of Development Economics, 73, 55-74. http://dx.doi.org/10.1016/j.jdeveco.2003.03.002

Darrat, A. F. (1999). Are financial deepening and economic growth causality related? Another Look at the Evidence. International Economic Journal, 13(3), 19-35.

De Gregorio, J., \& Gvidotti, P. E. (1995). Financial development and economic growth. World Development, 23, 433-448. http://dx.doi.org/10.1016/0305-750X(94)00132-I

Demetriades, P. O., \& Hussein, K. (1996). Does financial development cause economic growth? Time series Evidence from 16 countries. Journal of Development Economics, 51, 387-411. http://dx.doi.org/10.1016/S0304-3878(96)00421-X

DFID. (2004). The Importance of financial sector development for growth and poverty reduction.

Dickey, D., \& Fuller, W. (1981). Likelihood Ratio Statistics for Autoregressive Time series with a unit root. Econometrica, 49(4), 1057-1057. http://dx.doi.org/10.2307/1912517

Ghatak, S., \& Siddiki, J. (2001). The use of ARDL approach in estimating virtual exchange rates in India. Journal of Applied Statistics, 28, 573-583. http://dx.doi.org/10.1080/02664760120047906

Goldsmith, R. W. (1969). Financial structure and development. New York: Yale University press. 
Granger, C. W. J. (1969). Investigating Causal Relationship by Econometric Models and Cross Spectral Methods. Journal of Econometica, 37, 424-458. http://dx.doi.org/10.2307/1912791

Granger, C., \& Newbold, P. (1974). Spurious Regression in Econometrics. Journal of Econometrics, 2, 111-120. http://dx.doi.org/10.1016/0304-4076(74)90034-7

Greenwood, \& Jovanovich. (1990). Financial development, growth and distribution of income. Journal of Political Economy, 1076-1107. http://dx.doi.org/10.1086/261720

Gujarati, D. N. (1995). Basic Econometrics. Singapore: McGraw-Hill Book Co.

Harris, R. (1995). Using cointegration Analysis in econometric modeling. London: Prentice Hall/ Harvester Wheatsheaf.

Harris, R., \& Sollis, R. (2003). Applied time series modeling and forecasting. West Sussex: Wiley.

Johansen, S. (1988). Statistical analysis of co integration vectors. Journal of Economic Dynamics and Control, 12, 231-254. http://dx.doi.org/10.1016/0165-1889(88)90041-3

Johansen, S., \& Juselius, K. (1990). Maximum Likelihood Estimation and inference on Cointegration with applications to the Demand for money. Oxford Bulletin of Economics and Statistics, 52, 169-210. http://dx.doi.org/10.1111/j.1468-0084.1990.mp52002003.x

King, R. G., \& Levine, R. (2003). Finance and growth: Schumpeter might be right? Quarterly Journal of Economics, 108(3), 777-795.

King, R., \& Levine, R. (1993). Finance, entrepreneurship and growth: Theory and evidence. Journal of Monetary Economics, 32, 513-543. http://dx.doi.org/10.1016/0304-3932(93)90028-E

Levine, R. (1997). Financial development and economic growth. Journal of Economic Literature, 32(2), 688727.

Levine, R. (1997). Financial development and economic growth: view and agenda. Journal of Economic Literature, 35, 688-726.

Loesse, J. E. (2009). Co-integration and causality between financial development and economic growth: Evidence from ECOWAS countries. European Journal of Economic, 113-122.

Lucas, R. E. (1988). On the mechanism of economic development. Journal of Monetary Economics, 22, 3-42. http://dx.doi.org/10.1016/0304-3932(88)90168-7

Maddala, G. S., \& Kim, I. M. (1998). Unit Root, Co-integration and Structural change. UK: Cambridge Press.

Mah, J. S. (2000). An empirical examination of the disaggregated import demand of Korea-The case of information technology product. Journal of Asian Economic, 11, 237-244. http://dx.doi.org/10.1016/S1049-0078(00)00053-1

Mohd, A. I. (2012). An empirical analysis of causality between development of non-bank financial intermediaries and the economic growth in Malaysia. European Journal of Social Sciences, 30(4), 654-664.

Mohsen, M., \& Maysam, M. (2012). Energy consumption, financial development and economic growth: an ARDL approach for the case of Iran. International Journal of Business and Behavioral Sciences, 2(6), 92 99.

Mohsin, S. K., \& Abdelhak, S. S. (2000). Financial development and economic growth: An overview. IMF working Paper. WP/00/209.

Muhammad, S. D., \& Muhammad, U. (2010). The Bound testing approach for co-integration and causality between financial development and economic growth in the case of Pakistan. European Journal of Social Sciences, 13(4), 525-553.

Narayan, P. K. (2004). Reformulating Critical values for Bounds F-Statistics approach to co-integration: An application to the Tourism Demand model for Fiji. Discussion papers. Department of Economics, Monash University, Australia.

Narayan, P. K., \& Smyth, R. (2005). The residential demand for electricity in Australia: an application of the bounds testing approach to co-integration. Energy Policy, 33, 457-464. http://dx.doi.org/10.1016/j.enpol.2003.08.011

Ndebbio, J. E. U. (2004). Financial deepening, economic growth and development: Evidence from selected Sub-Saharan African Countries. African Economic Research Consortium (AERC), research Paper No.142. 
Odhiambo, N. M. (2004). Is financial development still a spur to economic growth? Causal evidence from South Africa. Savings and Development, 28(1), 47-62.

Odhiambo, N. M. (2008). Financial development in Kenya: a dynamic test of the Finance-led growth Hypothesis. Economic Issues, 13(2), 21-36.

Patrick, H. T. (1966). Financial development and economic growth in underdeveloped countries. Economic Development and Cultural Change, 14, 174-189. http://dx.doi.org/10.1086/450153

Pattichis, C. A. (1999). Price and Income elasticities of disaggregated import demand: results from UECMs and Application. Journal of Applied Econometrics, 31, 1061-1071. http://dx.doi.org/10.1080/000368499323544

Pesaran, H., Shin, Y., \& Smith, R. (2001). Bound Testing approaches to the analysis of level relationship. Journal of Applied Econometrics, 16, 289-326. http://dx.doi.org/10.1002/jae.616

Pesaran, M. H., \& Pesaran, B. (1997). Working with Microsoft 4.0: Interactive econometric analysis. Oxfors: Oxford University press.

Pesaran, M. H., \& Shin, Y. (1999). An autoregressive Distributed lag modeling approach to co-integration analysis. In S. Strong (Ed.), Chapter 11 in Econometrics and Economic Theory in the 20 the century: the Ragnar Frisch centennial symposium (pp. 371-413). Cambridge: Cambridge university press. http://dx.doi.org/10.1017/CCOL521633230.011

Phillips, P., \& Perron, P. (1988). Testing for a Unit Root in Time series Regression. Biometrika, 75(2), 336-346. http://dx.doi.org/10.1093/biomet/75.2.335

Rachdi, H., \& Mbarek, H. B. (2011). The causality between financial development and economic growth: Panel Data Co-integration and GMM system approaches. International Journal of Economics and Finance, 3(1), 143-151. http://dx.doi.org/10.5539/ijef.v3n1p143

Rao, M. A., Abida, J., Khalid, Z., Aisha, I., \& Rabia, S. (2010). Trade Liberalization, financial development and economic growth: Evidence from Pakistan (1980-2009). Journal of International Academic Research, 10, 30-38.

Republic of Kenya. (2007). Kenya Vision 2030: A Globally Competitive and Prosperous Kenya. Nairobi: Government Printer.

Republic of Kenya. (Various years). The Economic Survey. Nairobi: Government Printer.

Robinson, J. (1952). The rate of interest and other essays, chapter the generalization of the general theory (pp 67-142). London: Macmillan.

Songul, K. A., IIhan, O., \& Ali, A. (2009). Financial development and economic growth: Literature survey and empirical evidence from sub-Saharan African countries. Sajems, 1, 11-27.

Tang, T. C., \& Nair, M. (2002). A co integration analysis of Malaysian import demand function: Reassessment from the bound test. Applied Economics Letter, 9, 293-296. http://dx.doi.org/10.1080/13504850110073471

World Bank. (2011). World Development Report. New York: Oxford University Press.

\section{Copyrights}

Copyright for this article is retained by the author(s), with first publication rights granted to the journal.

This is an open-access article distributed under the terms and conditions of the Creative Commons Attribution license (http://creativecommons.org/licenses/by/3.0/). 